УДК 677.074

DOI: 10.17277/vestnik.2015.02.pp.305-311

\title{
RESEARCH AND SELECTION OF DRYING OPERATING PARAMETERS OF INTERMEDIATE PRODUCT FOR NICKEL CATALYSTS
}

\author{
M. K. Kosheleva ${ }^{1}$, S. P. Rudobashta ${ }^{2}$, M. S. Apalkova ${ }^{1}$ \\ Department "Processes, Apparatus of Chemical Technology and Life Safety" \\ Moscow State University of Design and Technology (1); \\ Department "Heat, Hydraulics and Enterprise Power Supply", \\ Russian State Agrarian University - Timiryazev Moscow State Agricultural Academy (2); \\ oxtpaxt@yandex.ru
}

Keywords: capillary-porous material; drying; dynamics; influence of hydrodynamics on grain size, kinetics and quality of the material; kinetics; temperature.

\begin{abstract}
The dynamics and kinetics of drying of intermediate product for nickel catalyst are studied. The unity of mass transfer mechanism in this material at different drying temperatures is shown. The temperature intervals of drying rational from the perspective of preserving the technological properties of the finished product and labor protection are determined. It is shown that the kinetics of drying of the studied object affects the hydrodynamic conditions in the machine. The influence of the size of dried granules on the kinetics of the drying process is researched. The possibility of an intensification of the drying process by decreasing the size of the drying object, by increasing temperature with the allowable attrition and the quality requirements of the finished product is shown.
\end{abstract}

The aim of the research is the selection of drying operating parameters of a typical capillary-porous material - intermediate product of nickel catalyst used in chemical technology, in particular for the conversion of methane. Drying of the intermediate Product Producing Catalyst (PPC) is important in providing the desired properties of the finished catalyst, and therefore the determination of operating parameters of rational drying PPC is of considerable interest.

Intermediate product of nickel catalyst - PPC is a typical capillary-porous body having micro pores and transient pores, transfer of moisture in which is carried out by combined mechanisms of mass transfer typical of capillary-porous materials (capillary transfer, membrane flow, tight vapor diffusion, and others.) [1-3]. PPC in its composition comprises kaolin, magnesium oxide, nitrate and nickel carbonate (apparent density of the material $-1250 \mathrm{~kg} / \mathrm{m}^{3}$, the true density $-1920 \mathrm{~kg} / \mathrm{m}^{3}$ ). As it was shown in the researches of PPC total pore volume is $0.28 \mathrm{~cm}^{3} / \mathrm{g}$, pore volume with a radius of $100 \AA$ is $0.03 \mathrm{~cm}^{3} / \mathrm{g}$, and the rest volume $\left(0.25 \mathrm{~cm}^{3} / \mathrm{g}\right)$ - is finer pores.

It is important to have information about the fields of moisture content of the drying facility for the technology-related research, in particular, when selecting drying. It gives an idea of some of the laws governing the internal moisture transfer. 


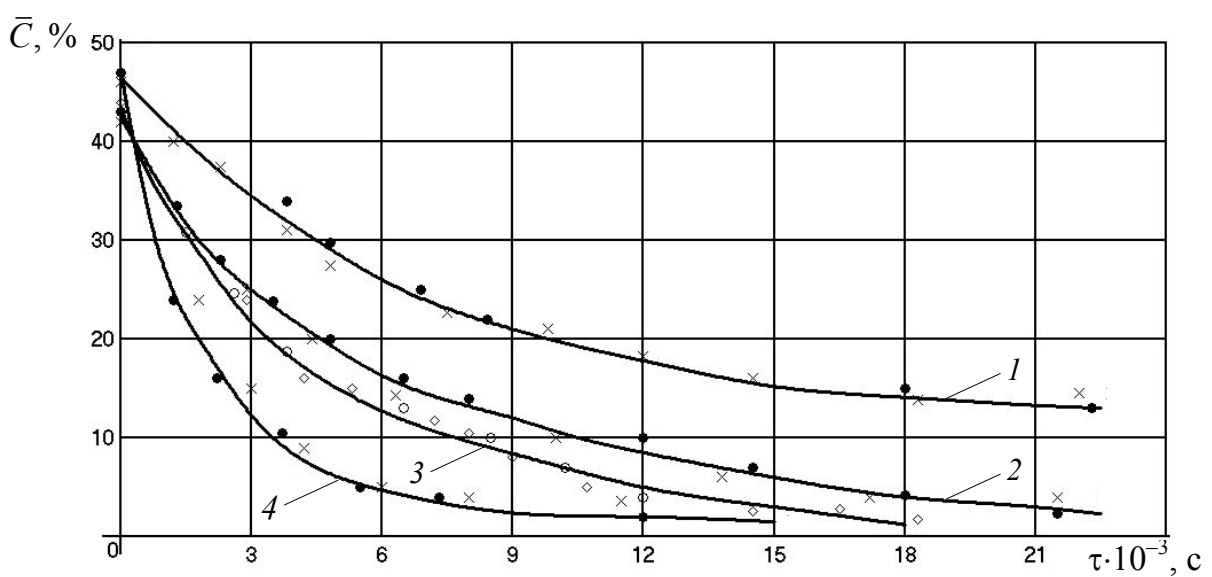

Fig. 1. $\bar{C}=f(\tau)$ dependence on drying PPC samples:

$1-t=80{ }^{\circ} \mathrm{C} ; 2-t=100{ }^{\circ} \mathrm{C} ; 3-t=120^{\circ} \mathrm{C} ; 4-t=150{ }^{\circ} \mathrm{C}$;

$\bullet, \circ-$ from the moisture fields; $\times, \diamond-$ kinetics of drying

The moisture distribution in the samples of PPC was determined by gravimetric method, its advantages over others are shown in the research [1]. Moisture fields were studied during the laboratory drying of model samples made of fine powder PPC because they satisfy the requirements to the object of the research moisture fields content by weight [1]. To eliminate the influence of thermal diffusion on mass conductivity in the drying process all experiments were carried out under the conditions close to isothermal, the samples were first incubated at a temperature of experience. The moisture distribution in the sample as described in [1] was analyzed in certain intervals, the local humidity values were calculated according to the dry material. Error weighting method is less than $0.5 \%$ moisture content [1].

As for the analysis of moisture field content, the average integral moisture content obtained from the distribution curves quite accurately coincided with their corresponding values on the drying kinetics curves obtained under the same conditions (Fig. 1).

It was found that the moisture field does not contain the test material inflection points in the range of humidity $((45 \pm 1) \%)$, the humidity on the surface decreases gradually, reaching an equilibrium value after $2-7$ hours from the beginning of the experiment (depending on the drying temperature).

The pattern of moisture content distribution determines the size of the sample and remains unchangeable - both at the temperature of the material below $100{ }^{\circ} \mathrm{C}$, and at the temperature above $100^{\circ} \mathrm{C}$, indicating that this material is a single mechanism for mass transfer throughout the range of temperatures tested $[1,2]$.

It is important for many capillary-porous and colloidal materials (product quality assurance) to have the value drops of moisture content within the material in the drying technology. The presence of excessive humidity fluctuations leads to disruption of the material structure (cracking, warping) [3].

Figure 2 shows the differences between the moisture content and the surface sections of the central test samples during drying at various temperatures.

Figure 3 shows the change in moisture content in the center and on the surface of dried samples PPC.

As follows from the graphs, the effect of temperature fluctuations on the moisture content in the material occurs at the temperature lower than $100{ }^{\circ} \mathrm{C}$ when the increase in temperature leads to the increase in the moisture gradient at the initial drying step, however, after reaching a maximum point of the decrease in the gradient at higher 


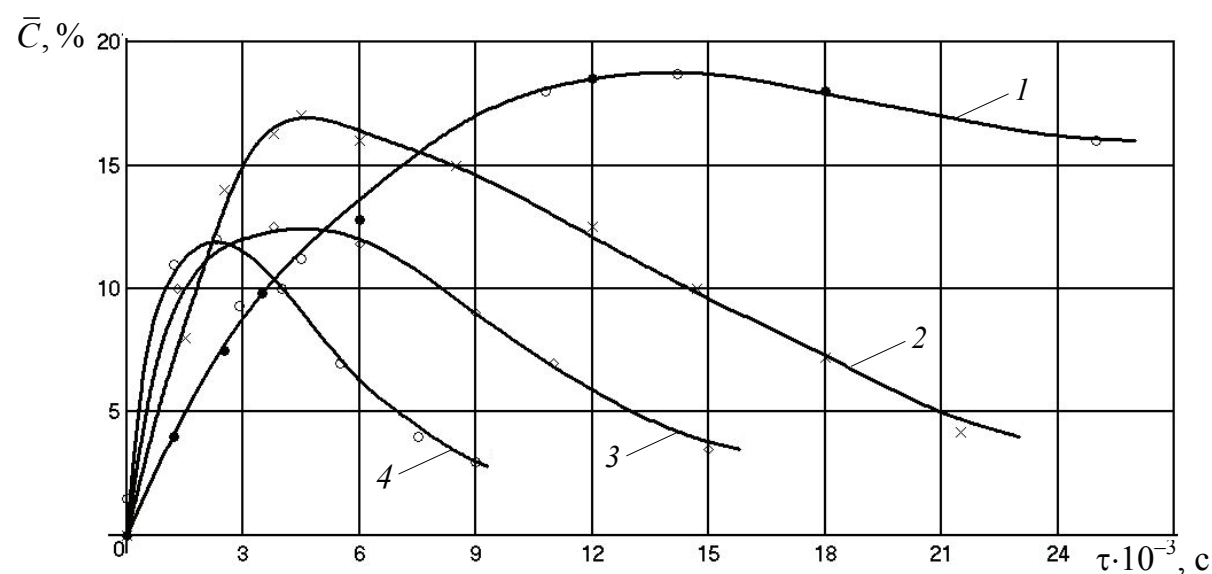

Fig. 2. $\Delta C=f(\tau)$ dependence on drying PPC samples: $1-t=80{ }^{\circ} \mathrm{C} ; 2-t=100{ }^{\circ} \mathrm{C} ; 3-t=120{ }^{\circ} \mathrm{C} ; 4-t=150{ }^{\circ} \mathrm{C}$;

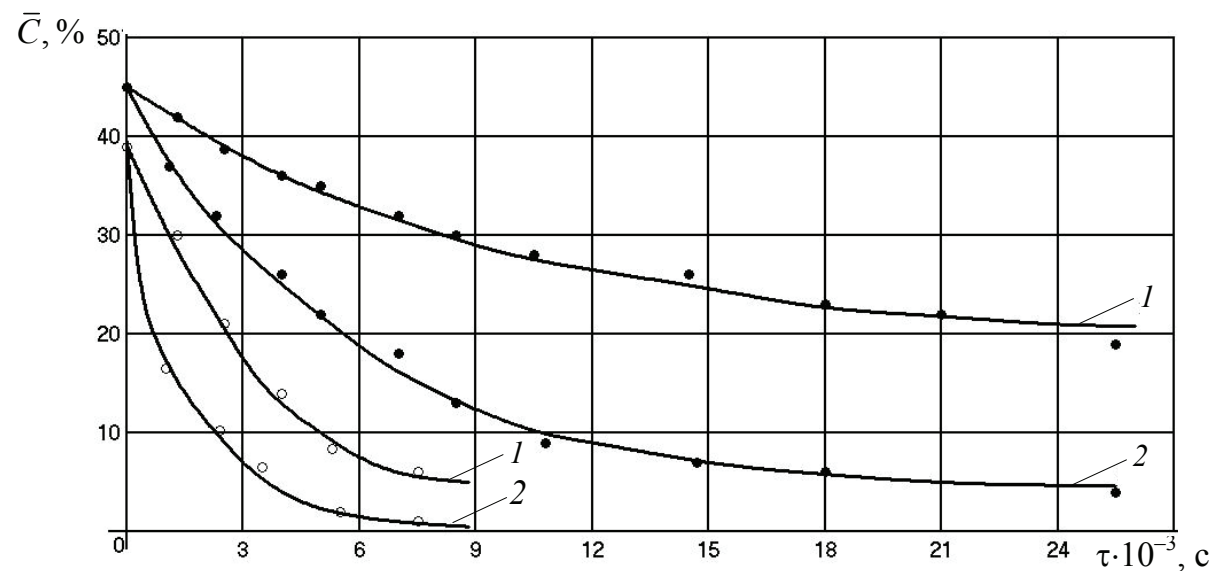

Fig. 3. $C_{\mathrm{c}}=f(\tau)$ и $C_{\mathrm{s}}=f(\tau)$ dependence on drying PPC samples:

1 - in the center; $2-$ on the surface; $\bullet-t=80^{\circ} \mathrm{C} ; \circ-t=150{ }^{\circ} \mathrm{C}$

humidity, drying gets faster and therefore the final drying step mode corresponding to higher temperature has lower moisture gradient values in the material.

At temperatures above $100{ }^{\circ} \mathrm{C}$ the increase in the temperature at the initial stage of drying does not lead to the increase in the moisture gradient, while at the final stage there is a picture similar to that which occurred in the development of the field at a temperature below $100{ }^{\circ} \mathrm{C}$ : if the temperature is higher, the humidity difference in the body is lower.

The consideration of the dynamics of the field moisture content in the material is explained mainly by the temperature and concentration dependence of the coefficients of mass transfer and mass conductivity. A significant decrease in the mass conductivity of the test material is obviously connected with the decrease in moisture content. In the process of drying this circumstance leads to the fact, that decrease in moisture moves the mass transfer problem to steadily internal diffusion region [1].

In this connection, at the first stage of the drying process the kinetics affects both external and internal diffusion, so increase in drying temperature affects the moisture in the material drops both in mass conductivity coefficient and in the mass transfer coefficient. At the final stages of drying the role of the external resistance is small, and gradients are formed in the body, the value of which is determined by the mass 
conductivity coefficient. The increase in the temperature in these conditions, causing a significant increase in mass conductivity coefficient, leads to natural moisture reduction gradients in a material.

Based on the analysis of variations in humidity in the material it can be concluded that the drying process PPC holding at $t=120 \ldots 150^{\circ} \mathrm{C}$ is characterized by lower values of moisture drops than $t \sim$ at $100^{\circ} \mathrm{C}$. It should cause less mechanical stresses in the material and, therefore, less dusting and cracking of the catalyst.

Thus, the research allowed us to recommend drying process conditions in the temperature range $120 \ldots 150{ }^{\circ} \mathrm{C}$, as more suitable from the perspective of preserving the technological properties of the product and safety (due to hazard of catalyst dust).

Drying of PPC flows in an environment with the kinetics of the process is significantly affected by the hydrodynamic conditions in the machine. Figure 4 shows curves of drying granules PPC $0.01 \mathrm{~m}$ in diameter and a length of $0.02 \mathrm{~m}$ measured at various air flow rates.

With the increase in the speed from about 5 to about $11 \mathrm{~m} / \mathrm{s}$, the drying time of the material at $120^{\circ} \bar{C}_{\mathrm{S}}=45 \%$ to $\bar{C}_{\mathrm{f}}=4 \%$ reducing $\sim 40 \%$, a further increase in speed has no appreciable effect on the processing time.

This is explained by the fact that at speeds higher than $10 \mathrm{~m} / \mathrm{s}$ the external resistance is virtually removed and the problem moves to internal kinetics. Consequently, the reduction in the drying time of the catalyst by increasing the rate of coolant is only possible in the range of $V<10 \mathrm{~m} / \mathrm{s}$.

The research into the effect of the size on the kinetics of dried granules process was also conducted (Fig. 5). When drying up from $\bar{C}_{\mathrm{S}}=45 \%$ to $\bar{C}_{\mathrm{f}}=4 \%$ the change of determined size from $0.02 \mathrm{~m}$ to $0.01 \mathrm{~m}$ reduces the drying time $\sim 25 \%$, and from $0.01 \mathrm{~m}$ to $0.005 \mathrm{~m}$ by $12 \%$. These data allow us to assess the effect of intensifying the process by reducing the size of the granules.

Granules PPC are to a certain extent easily abradable (dusting material). Due to hazard of dust and further processing conditions, the drying process tends to be carried out at the conditions excluding increased abrasion of the granules. Internal stresses in the material, leading to the development of micro cracks help to increase its resistance to abrasion. These stresses arise in the material due to large differences in moisture content and the temperature through the thickness of the material [3].

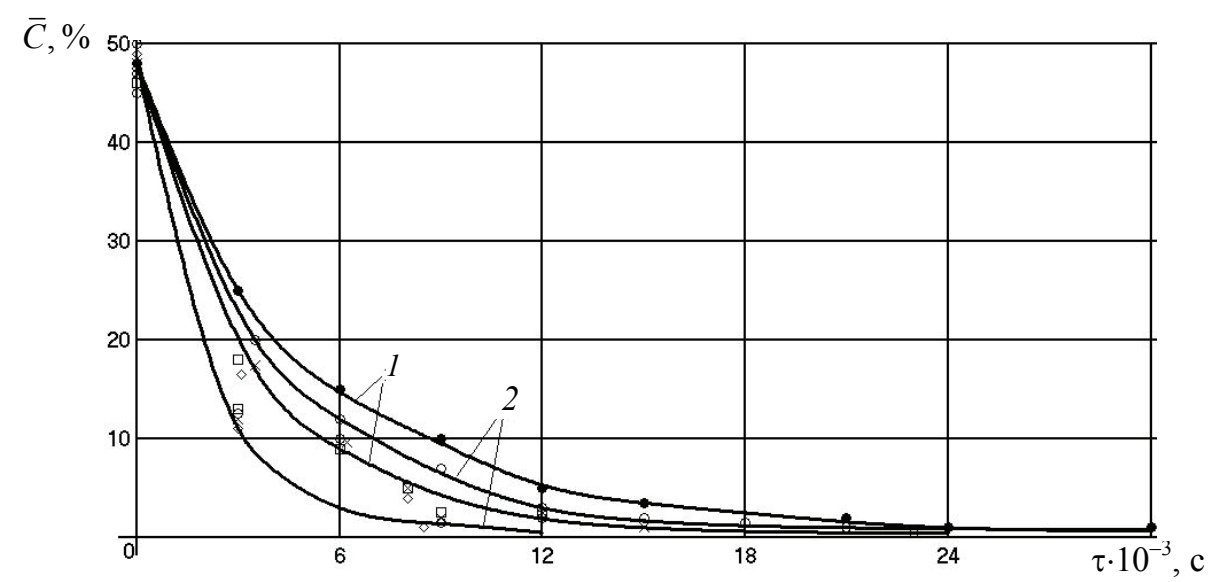

Fig. 4. Drying curves for different speeds of the air flow: $\left(2 R=1 \cdot 10^{-2} \mathrm{~m}, l=2 \cdot 10^{-2} \mathrm{~m}\right)$;

$1-t_{\mathrm{c}}=100{ }^{\circ} \mathrm{C} ; 2-t_{\mathrm{c}}=120^{\circ} \mathrm{C} ; \bullet-v_{\mathrm{c}}=4,8 \mathrm{~m} / \mathrm{s} ; \times-v_{\mathrm{c}}=11,6 \mathrm{~m} / \mathrm{s} ;$

$\diamond-v_{\mathrm{c}}=20,3 \mathrm{~m} / \mathrm{s} ; \square-v_{\mathrm{c}}=26,2 \mathrm{~m} / \mathrm{s} ; \circ-v_{\mathrm{c}}=16,4 \mathrm{~m} / \mathrm{s}$ 


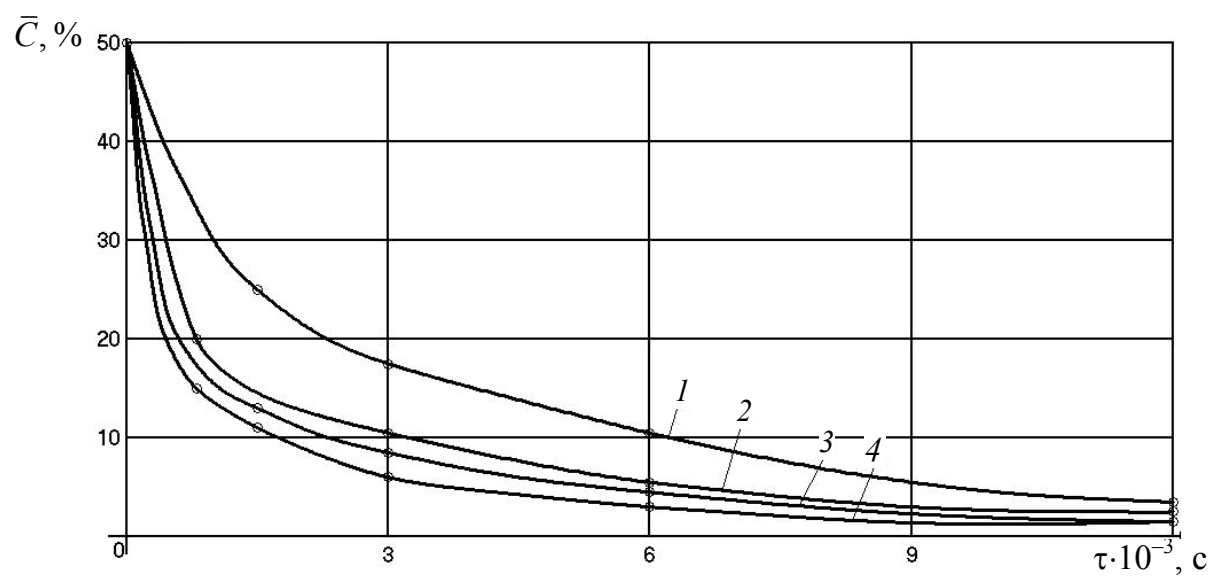

Fig. 5. Influence of sample size on the kinetics of drying PPC:

$$
\begin{gathered}
\left(t_{\mathrm{c}}=100^{\circ} \mathrm{C} ; v_{\mathrm{c}}=25 \mathrm{~m} / \mathrm{s} ; 2 R=1 \cdot 10^{-2} \mathrm{~m}\right) ; \\
l-l=2 \cdot 10^{-2} \mathrm{~m} ; 2-l=1 \cdot 10^{-2} \mathrm{~m} ; 3-l=0,5 \cdot 10^{-2} \mathrm{~m} ; 4-l=0,2 \cdot 10^{-2} \mathrm{~m}
\end{gathered}
$$

The survey showed that the moisture content of the fields, increase in the drying temperature to $100{ }^{\circ} \mathrm{C}$ PPC is accompanied by the increase in moisture content gradients. Further growth of the temperature (up to $150^{\circ} \mathrm{C}$ ) causes reduction of these differences, but their development in time occurs more rapidly. In general, the resulting effect of stresses in the material when the temperature rises from $100{ }^{\circ} \mathrm{C}$ to $150{ }^{\circ} \mathrm{C}$ due to the presence of oppositely acting factors (moisture reduction gradients and the increase in the speed of formation of the material) may be such that the drying conditions at $120 \ldots 150{ }^{\circ} \mathrm{C}$ will not be worse in abrasion than at $100^{\circ} \mathrm{C}$.

Thus, possible material intensification of the drying process by increasing the temperature of the drying agent from $100 \ldots 120^{\circ} \mathrm{C}$ to $120 \ldots 140^{\circ} \mathrm{C}$ given the allowable abrasion requirements of the product and its quality should be considered.

Conclusion. The intermediate product of nickel catalyst - PPC is a typical capillary-porous body having micro pores and transient pores, transfer of moisture in which is carried out by combined mechanisms of mass transfer characteristic of capillary-porous materials (capillary transfer, membrane flow, tight vapor diffusion, and others).

The dynamics of drying PPC was researched. The unity mass transfer mechanism in the drying material at a temperature either below or above $100{ }^{\circ} \mathrm{C}$ was shown. The temperature intervals of drying rational from the point of view of preserving the technological properties of the finished product and labor protection were determined.

It was shown that the kinetics of drying PPC affects the hydrodynamic conditions in the machine. The influence of the size of dried granules PPC on the kinetics of the drying process was researched. The possibility of accelerating the process by reducing the size of the drying object was shown. In addition, the intensification of the process can be achieved by increasing the temperature of the material because of its allowable attrition and the quality requirements of the finished product.

\section{References}

1. Rudobashta S.P. Massoperenos v sistemakh s tverdoi fazoi (Mass transfer in systems with solid phase), Moscow, Chemistry, 1980, 248 p.

2. Sazhin B.S., Kosheleva M.K., Sazhina M.B. Protsessy sushki i promyvki tekstil'nykh materialov (Processes of drying and washing of textiles), Moscow: RIO MGUDT, 2013, 301 p.

3. Lykov A.V. Teoriya sushki (Theory of Drying), Moscow: Energy, 1968, 472 p. 


\title{
Исследование и выбор режимных параметров процесса сушки промежуточного продукта получения никелевого катализатора
}

\author{
М. К. Кошелева ${ }^{1}$, С. П. Рудобашта ${ }^{2}$, М. С. Апалькова ${ }^{1}$ \\ Кафедра «Проиессы, аппараты химической технологии \\ и безопасность жизнедеятельности», ФГБОУ ВПО «Московский \\ государственный университет дизайна и технологии» (1); \\ кафедра «Теплотехника, гидравлика и энергообеспечение предприятий», \\ ФГБОУ ВО «Российский государственный аграрный университет - \\ МСХА имени К. А. Тимирязева»(2), г. Москва; охtpaxt@yandex.ru
}

Ключевые слова: влияние гидродинамики, температуры, размера гранул на кинетику и качество материала; динамика; капиллярно-пористый материал; кинетика; сушка.

Аннотация: Исследованы динамика и кинетика сушки промежуточного продукта получения никелевого катализатора. Показано единство механизма массопереноса в данном материале при различных температурах сушки. Определены температурные интервалы сушки, рациональные с точки зрения сохранения технологических свойств готового продукта и охраны труда. Показано, что на кинетику сушки объекта исследования оказывает влияние гидродинамическая обстановка в аппарате. Исследовано влияние размера высушиваемых гранул на кинетику процесса его сушки. Показана возможность интенсификации процесса сушки при уменьшении размеров объекта сушки, повышении его температуры с учетом допустимой истираемости и требований к качеству готового продукта.

\section{Список литературы}

1. Рудобашта, С. П. Массоперенос в системах с твердой фазой / С. П. Рудобашта. - М. : Химия, 1980. - 248 с.

2. Сажин, Б. С. Процессы сушки и промывки текстильных материалов / Б. С. Сажин, М. К. Кошелева, М. Б. Сажина. - М. : РИО МГУДТ, 2013. - 301 с.

3. Лыков, А. В. Теория сушки / А. В. Лыков. - М. : Энергия, 1968. - 472 с.

\section{Forschung und Auswahl der Regimeparameter des Prozesses des Trocknens des Zwischenproduktes des Erhaltens des Nickelkatalysators}

Zusammenfassung: Es sind die Dynamik und die Kinetik des Trocknens des Zwischenproduktes des Erhaltens des Nickelkatalysators untersucht. Es ist die Einheit des Mechanismus der Massenübertragung im gegebenen Material bei den verschiedenen Temperaturen des Trocknens gezeigt. Es sind die Temperaturintervalle des Trocknens, die vom Gesichtspunkt der Erhaltung der technologischen Eigenschaften des fertigen Produktes und des Arbeitsschutzes rational sind, bestimmt.

Es ist gezeigt, dass auf die Kinetik des Trocknens des Objektes der Forschung die hydrodynamische Lage im Apparat beeinflusst. Es ist der Einfluss des Umfanges der austrocknenden Granula auf die Kinetik des Prozesses des Trocknens untersucht. Es ist die Möglichkeit der Intensivierung des Prozesses des Trocknens bei der Verkleinerung der Größe des Objektes des Trocknens, bei der Erhöhung seiner Temperatur unter Berücksichtigung der zulässigen Abnutzbarkeit und der Forderungen zur Qualität des fertigen Produktes gezeigt. 


\section{Étude et choix des paramètres de régime du processus du séchage du produit intermédiaire de l'obtention du catalyseur de nickel}

Résumé: Est étudiée la dynamique et la cinétique du séchage du produit intermédiaire de l'obtention du catalyseur de nickel. Est montrée l'unité du mécanisme du transfert de masse dans le matériel donné lors de différentes température du séchage. Sont définis les intervalles de température du séchage qui sont rationnels du point de vue de la conservation des propriétés technologiques du produit fini et de la sécurité du travail.

Est montré que sur la cinétique du séchage de l'objet influence l'entourage hydrodynamique dans l'appareil. Est étudiée l'influence de la dimension des granules séchés sur la cinétique du processus du séchage.

Est montrée la possibilité de l'intensification du processus du séchage pendant la diminution des dimensions des objets du séchage, pendant l'augmentation de sa température compte tenu de la volatilité admissible et les qualités envers le produit fini.

Авторы: Кошелева Мария Константиновна - кандидат технических наук, профессор кафедры «Процессы, аппараты химической технологии и безопасность жизнедеятельности», ФГБОУ ВПО «Московский государственный университет дизайна и технологии», г. Москва; Рудобашта Станислав Павлович - доктор технических наук, профессор кафедры теплотехники, гидравлики и энергообеспечения предприятий, ФГБОУ ВО «Российский государственный агроинженерный университет - МСХА им. К. А. Тимирязева», г. Москва; Апалькова Марина Сергеевна - аспирант кафедры «Процессы, аппараты химической технологии и безопасность жизнедеятельности», ФГБОУ ВПО «Московский государственный университет дизайна и технологии», г. Москва.

Рецензент: Гатапова Наталья Цибиковна - доктор технических наук, профессор, заведующая кафедрой «Технологические процессы, аппараты и техносферная безопасность», ФГБОУ ВПО «ТГТУ». 